\title{
Encouraging Green ICT Implementation Strategies in Polytechnic Education in Ghana
}

\author{
Nana Yaw Asabere, PhD \\ Computer Science Department \\ Accra Polytechnic \\ P.O. GP 561, Accra, Ghana
}

\author{
Amevi Acakpovi \\ Electrical/Electronics \\ Engineering Department \\ Accra Polytechnic \\ P.O. GP 561, Accra, Ghana
}

\author{
Nii Quaynor \\ Electrical/Electronics \\ Engineering Department \\ Accra Polytechnic \\ P.O. GP 561, Accra, Ghana
}

\begin{abstract}
Green ICT is the study and analysis of creating, improving and sustaining environmental ICT practices in an organization. Globally, innovative educational institutions focus on utilizing ICT such as lecture video recordings, lecture broadcasts, learning images, texts, and worksheets for idea generation and teaching/lecture purposes. Using Accra Polytechnic in Ghana as a case study, this paper analyzes the possible ways that educational institutions can implement green ICT in order to ensure that their environment is economically sustainable. This research aims at further increasing awareness regarding the advantages and limitations on green ICT in Ghana in addition to providing guidelines for ICT utilization. The goal of the green ICT/computing is to reduce the use of hazardous materials found in computer systems; to maximize the product lifetime and to promote recyclability and biodegradability of defunct and factory waste products. This paper therefore discusses different approaches such as server virtualization, PC and printer consolidation, active power management, central inverter systems and upgrading ICT equipment. Such strategies will enable educational institutions in Ghana, specifically, Accra Polytechnic to sustain their environment when undergoing ICT practices and procedures.
\end{abstract}

\section{General Terms}

Green ICT, Polytechnic Education.

\section{Keywords}

Green ICT, Strategies, ICT, Polytechnic Education, Energy, Ghana

\section{INTRODUCTION}

Globally, improving environmental performance, tackling global warming and enhancing resource management are high on the list of challenges that require urgent attention. The Information and Communications Technology (ICT) industry needs to further improve its environmental performance. ICT is responsible for about 2-3\% of the global carbon footprint and ICT applications which constitute $97-98 \%$ have a very large potential of enhancing performance across an economy and society [1]. Governments and business associations have introduced a range of programmes and initiatives on ICT and the environment to address environmental challenges, particularly global warming and energy use.

ICT is infusing all sectors of the economy everywhere in the world. This has increased the uptake of technologies that has introduced challenges to ICT personnel managing them. The high rates at which the technologies are changing has become more complicated for a developing nation such as Ghana. In general, green ICT refers to the study and analysis of creating, improving and sustaining environmental ICT practices in an organization [1]-[3]. Different organizations and educational institutions have been introduced to the task of analyzing the usage of different ICT equipment/facilities [4]. Common ICT facilities involve data centre equipment; mail servers, databases, firewalls and file servers; wireless and connected hubs, routers and networking equipment, smart phones, printers, scanners, projectors and copiers [1]-[4].

ICT professionals are expected to play substantial roles in introducing Green ICT to organizations, provided they are prepared to develop necessary capabilities that will lead and support sustainable initiatives [4]. Such prepared personnel would always be aware of what it is, and how it should be implemented to achieve its objective. ICT usage promises a lot of gains to business settings, however, it is not without side effects especially, environmental impacts. ICT has both positive and negative impacts in its use and production. In order for ICT to be applied to minimize its negative impact and maximize its positive impact in a manner that ensures the achievement of sustainable resource utilization, ICT personnel have to be educated on how to employ ICT tools and services effectively and efficiently. It is in this regard that, green ICT has emerged as a significant tool that can be used to reduce the direct environmental impact of designing, manufacturing, using and disposing of computers, servers and associated subsystems [1], [3], [4].

Green ICT requires the management of various institutions to look at the definite methods that can be used to analyze the techniques of mining ICT materials; the conditions under which they are manufactured and used; the means of transporting them to consumer; the equipment energy consumption and how the equipment are disposed of at the end of their lifetime. Green ICT is beneficial to companies, the environment and society [1]-[4].

Generally, much more needs to be done in developing and applying clear and measurable policies and initiatives to improve environmental performance of ICTs, and to apply ICTs across the economy to tackle the challenges of global warming and environmental degradation. In particular, policies and initiatives can encourage improvement of environmental performance along the entire ICT life cycle and promote ICT applications to make the life cycles of non-ICT sectors more resource efficient [1]. "Smart" urban, transport and power distribution applications and systems are promising avenues to reduce pollution, and these areas could benefit greatly from increased ICT policy attention, particularly in the 
current economic setting of recession and low resource prices [1], [4].

The purpose of this paper is to outline possible green ICT implementation procedures for tertiary institutions in Ghana, specifically, Accra Polytechnic. This research will help to further increase the understanding of the concept of green ICT and options of ICT usage. Furthermore, this research will help to understand the extent to which an ICT personnel capacity is prepared for implementation of green ICT. It will also inform policy makers in the development of an ICT policy based on the level of awareness of the personnel on green ICT.

\section{GREEN ICT CONCEPT}

The proliferation of costs which involve the pursuance of business in an ICT environment and stronger international commitment to decrease greenhouse gas emissions and attain other environmental goals is bound to create pressure to find effective ways/procedures of achieving greater efficient use of energy and other resources while sustaining economic growth [3]. It has been proved that green ICT has the ability to achieve environmental sustainability [1]-[8].

Globally, amongst different people and places, there are different definitions for green ICT. This has led to a lack of a standard agreed upon definition. Some perceive it to be green IT while others refer to it as green computing or green information systems [4], [5]. It is important for a nation to understand what green ICT is, for businesses to engage with it, and for our decision makers to be aware of its consequences and potentials in helping us get to a sustainable world [6], [7].

Unfortunately, there is disparity in the level of green ICT understanding, causing confusion within the human personnel [8]. This lack of a completely agreed upon definition makes it difficult to measure the effectiveness or the extent of an organization's implementation of green ICT [6]. Hence, many do not know how or where to begin and are unwilling to implement it [1], [4], [6], [8]. According to Hart [7] green computing is the study and practice of using computing resources efficiently. Green IT is said to be the optimal use of ICT for managing the environmental sustainability of enterprise, its operations, products, services and resources [2], [8]. From this viewpoint, green ICT is a process that focuses on strategic deployment of operations and ICT to dynamically, sustainably and responsibly align business goals with green objectives [1].

Research has shown that many green ICT approaches that focus on a business point of view of saving costs, reduces green ICT to energy and cost efficiency. This unfortunately makes green ICT to be undertaken in terms of hardware equipment utilization rather than organizational impact of ICT [4]. This assertion is supported by a survey by Wabwoba et al . [4] whose findings indicated that the most important motivation for adopting green ICT practices in Kenya was to reduce costs. From this perspective, green ICT towards sustainability has become a significant issue in the narrow sense while less attention has been paid in the broad view.

The main purpose of green ICT is to increase energy efficiency and to conserve energy for the coming future. Green ICT is becoming a mandatory act since organizations are concerned with the costs they are incurring and with the level of energy they save for their future business [9]. Green ICT can be also defined in terms of reusing, recycling and disposing of hardware. It should include all the business solutions that require very low carbon emission. Teleconferencing and videoconferencing are some ICT examples [10]. The goal of the green computing is to reduce the use of hazardous materials that build computer systems; to maximize the products lifetime and to promote the recyclability or biodegradability of defunct and factory waste products [1]-[6].

\subsection{The Role of Awareness and Acceptance of Technology}

Green ICT begins with technology awareness and acceptance of ICT personnel [11]. Awareness among ICT personnel plays a significant role in the deployment and implementation of green ICT [12]. Technology awareness and acceptance has an effect on perceived usefulness and perceived ease of use of technologies that have been found in technology adoption theories such as the Theory of Planned Behavior (TPB), Technology Acceptance Model (TAM), Technology Acceptance Model 2 (TAM 2), combined TAM and TPB (CTAM-TAB), Unified Theory of Acceptance and Use of Technology (UTAUT), Theory of Reasoned Action (TRA), Social Cognitive Theory (SGT), Innovation Diffusion Theory (IDT) and Decomposed Theory of Planned Behaviour (DTPB) [13], [14]. A diagram depicting TAM 2 is illustrated in Figure 1. Using TAM [13] as the starting point, TAM2 [14] integrates additional theoretical concepts spanning social influence processes (subjective norm, voluntariness, and image) job relevance, output quality, result demonstrability, and perceived ease of use. People naturally commit themselves on activities and tasks they have an idea about. It has been emphasized that in countries where environmental education has been included into the education curriculum at all levels, embracing pro-environmental attitudes is a reality. [4], [11], [12].

Clearly, when people are made aware of green ICT, they are more likely to implement it. According to Hamid et al. [12], a gradual increase in people's awareness and acceptance of technology in the developed world has created a relatively cleaner environment in comparison to the developing countries [12]. Lack of technology awareness and acceptance often results in organizations failure to seek opportunities that can be achieved with its adoption and implementation [15]. Lack of awareness has been reported to hinder acceptance and application of technology [16]. The decision to invest in, adopt and implement green ICT will be difficult to arrive at when organizations are unaware of the potential benefits they can derive from such an undertaking.

\section{SIGNIFICANCE OF GREEN ICT}

Green computing is vital due to the benefit that it provides to the environment and the general society. Murugesan and Laplante [8] mentioned that, barriers of implementing green ICT occur because as stated above, many people do not really understand what green ICT is [11]. People should know that the main benefit of implementing green ICT is the reduction of energy usage and implementation of techniques that reduce the emission of carbon at network data centres and lower the amount of computer hardware needed by firms [12], [24]. 
Table 1. Summary of Green ICT Benefits

\begin{tabular}{|c|c|}
\hline Category/Classification & Benefit \\
\hline Companies/Organizations & $\begin{array}{l}\text { - Less hardware required } \\
\text { - Reduced cost consumption } \\
\text { - Reduced energy costs } \\
\end{array}$ \\
\hline Environment/Society & $\begin{array}{l}\text { - Lower carbon emissions } \\
\text { - Reduced cost of data centres } \\
\text { - Compliance with legal requirements }\end{array}$ \\
\hline
\end{tabular}

The green peace movement in 2006 released a study that analyzed five leading brands of computers and laptop producers. The research revealed that the components of these computer brands were very hazardous and harmful to the environment. The computers had chemicals that could cause cancer, immune reactions and nerve damages in humans. The implementation of the green ICT helps in the reduction of such health hazards that can harm different users of ICT [17], [24].

As shown in Table 1, another importance of green ICT implementation involves the overall issue of decreasing the energy and carbon cost [8]. Millions of corporate institutions in the world use technology for communication and presentation to the investors. The opportunity of reducing operation costs by going green has been seen to be an innovative approach that different individuals in the organization are seen to uphold as an institution. The rising cost of operations that involve electricity in organization could be reduced by the implementation of the green economies by the organization. Green ICT implementation is thus important in reducing management carbon and electricity costs [1]-[8], [24].

The implementation of green ICT has enabled different firms to develop new ways of making profit, thereby reducing their overall financial risk. The rise in the digital world has enabled and equipped different consumers and company stakeholders on the overall disadvantages that certain industries in the organization have been seen to produce due to the carbon emission [18], [24]. The impact of the change was over the environmental issues on the brand values and customers behaviors.

\section{GREEN ICT AND CLIMATE CHANGE IN GHANA}

Developing countries are experiencing major growth in the deployment of ICT, and Ghana is no exception. According to 2010 ITU's ICT Development Index, Ghana is in tenth position out of 33 countries ranked in Africa. The rapid expansion of Ghana's ICT industry provides fertile ground for fostering and strengthening the use of ICT tools in adapting to climate change. The ICT sector in Ghana is currently witnessing the following: (i) rapid growth in mobile penetration, (ii) internet exchange, and (iii) the e-government network, just to mention a few [19].

Green ICT is very rare and has not been implemented widely in most organizations in Ghana. However, Ghana has been pro-active in the field of climate change for many years, playing a significant role in international negotiations (including hosting several international workshops and conferences in the fields of climate change adaptation and mitigation). Ghana ratified the UNFCCC in 1995 and the Kyoto Protocol in 2002 [19].

Ghana's new National Climate Change Committee which was

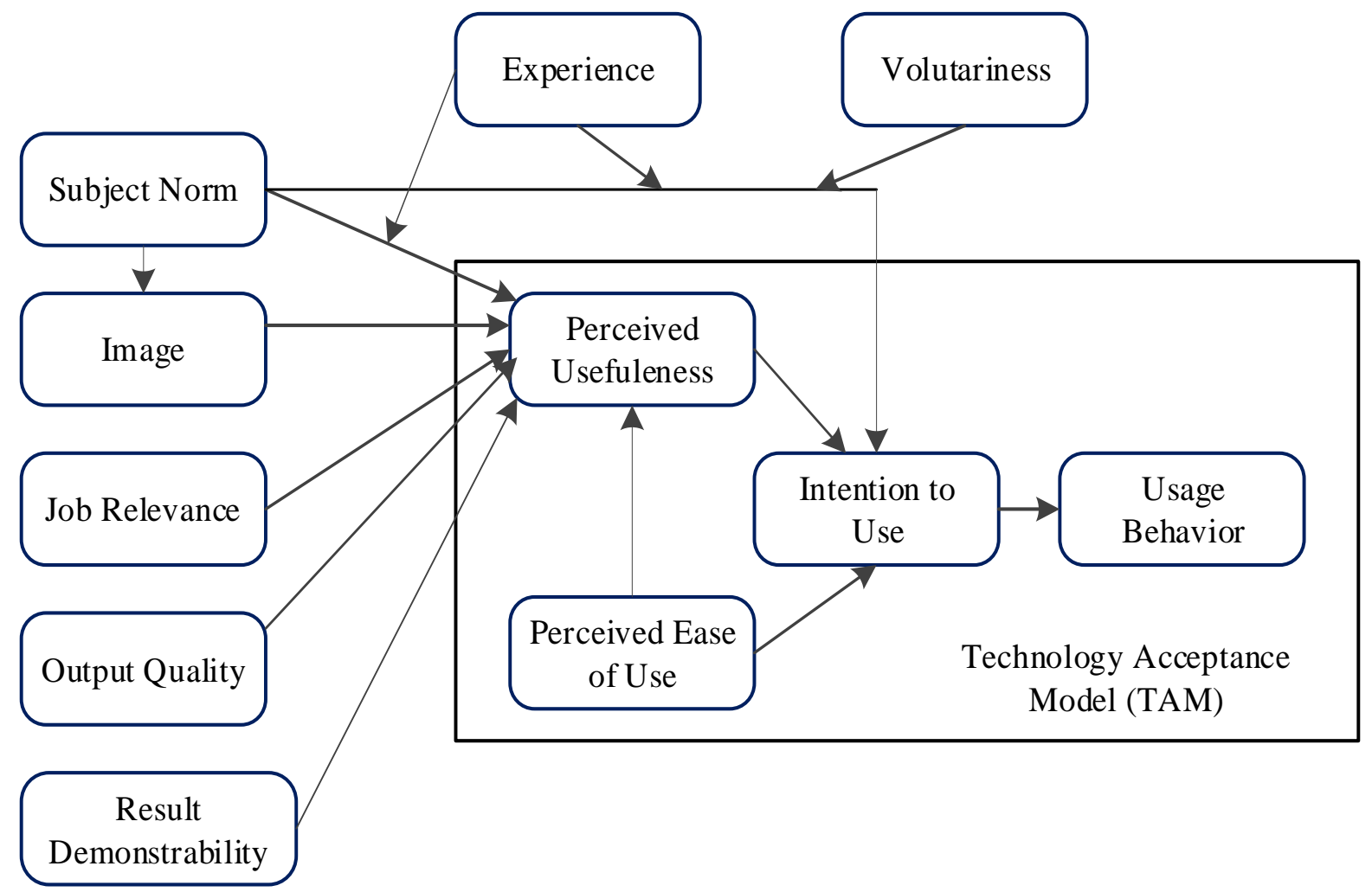

Fig. 1: Technology Acceptance Model 2 (TAM2) 

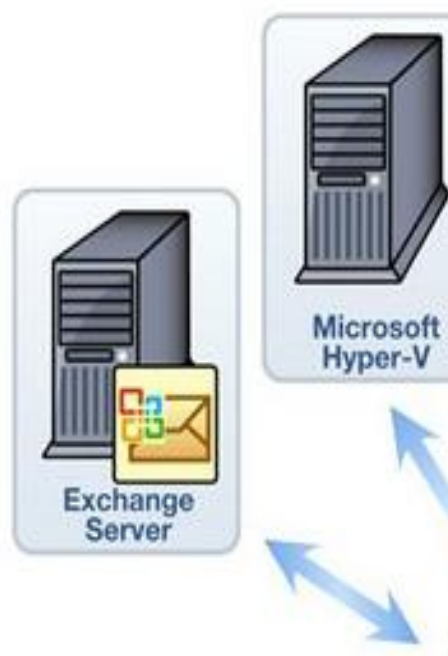

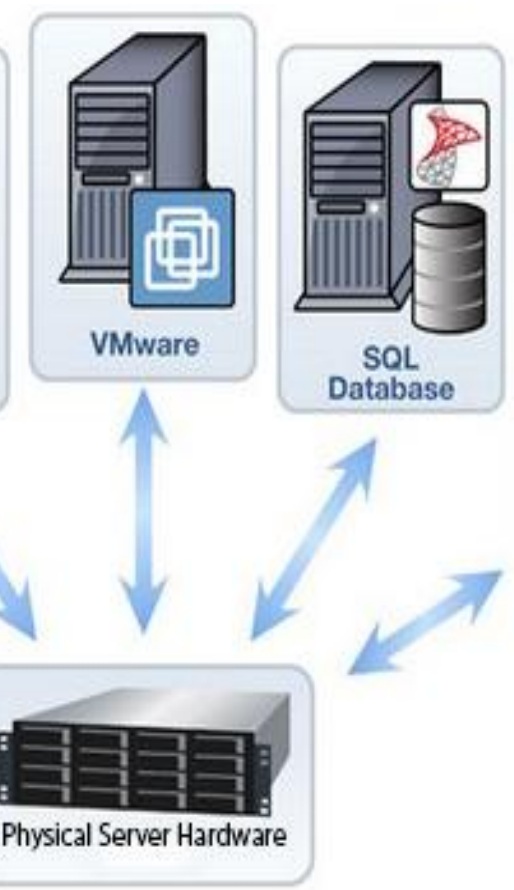

Fig. 2: Server Optimization/Virtualization

hosted by the Ministry of Environment, Science and Technology, published in November 2010 a discussion paper "Ghana goes for green growth". In the paper, John Dramani Mahama, the then Vice-President of Ghana (now President) and Chair of Ghana's Environmental and Natural Resource Advisory Council states that "We cannot allow climate change to pull us back. The only way we can go forward, developmentally, is to address its impact and to seize any opportunities it presents" [19].

The aim of the National Climate Change Policy Framework, as set out in the discussion paper, is "to ensure a climateresilient and climate compatible economy while achieving sustainable development and equitable low carbon economic growth for Ghana". The policy has three main objectives: low-carbon growth; effective adaptation to climate change; and socio-economic development. Successive governments and the people of Ghana have come to realize that the process of democratic governance can only be guaranteed if it is based on a sound socio-economic framework that is environmentally sustainable. Various practical steps related to ICT can be taken to implement this policy. Passive sharing of infrastructure such as masts and antennas are already occurring in Ghana. Sharing of utility poles to provide both electricity supply and network connectivity should also be encouraged, given that half the population lacks access to grid electricity [19].

Sharing of infrastructure should be encouraged when networks are expanded to deliver capacity to new base stations (for wireless broadband), schools and libraries (for fixed access) and individual homes (for full roll-out). ITU has developed many standards to reduce e-waste and decrease energy consumption. For example, Recommendation ITU-T L.1000 for a universal energy-efficient mobile phone charger will save up to 82000 tonnes of redundant chargers a year and at least 13.6 million tonnes of $\mathrm{CO}_{2}$ annually. Such standards should be adopted in Ghana [19].

It is important for Ghana, and indeed for Africa as a whole, to participate in ITU-T Study Group 5's work on ICT and climate change to ensure that the methods the group is developing are relevant to their needs. The regulatory framework should ensure that greenhouse gas emissions are reduced to a sustainable level. But it should not stifle the processes of liberalization, increasing efficiency and

Table 2. Staff Communications

\begin{tabular}{|c|l|l|}
\hline S/No. & Action & Rationale \\
\hline 1. & $\begin{array}{l}|c| \\
\text { Accra Polytechnic should promote energy } \\
\text { awareness to staff. }\end{array}$ & $\begin{array}{l}\text { The biggest contributors to climate change are us and the way we } \\
\text { conduct our everyday lives. People in Accra Polytechnic need } \\
\text { advice and feedback to encourage appropriate changes to their } \\
\text { behaviour. This is necessary due to the huge waste of energy } \\
\text { occurring on daily basis at Accra Polytechnic. Power consuming } \\
\text { equipment such as light ACs and computers are mostly left turned- } \\
\text { on during closing hours without any automatic control measure. }\end{array}$ \\
\hline 2. & $\begin{array}{l}\text { Managers, Senior Members and Senior } \\
\text { Staff in Accra Polytechnic should be } \\
\text { provided with information about their } \\
\text { service. }\end{array}$ & $\begin{array}{l}\text { Monitoring is very important in controlling energy consumption of } \\
\text { appliances. They should therefore be provided with energy and } \\
\text { paper consumption information so that managers in Accra } \\
\text { Polytechnic can compare their service with others and assess the } \\
\text { impact of any changes they make. }\end{array}$ \\
\hline
\end{tabular}


continuous innovation, which foster a diverse and growing market. Sustainability and development should go hand in hand [19].

\section{STRATEGIES FOR GREEN ICT IMPLEMENTATION}

\subsection{Background and Overview of Current} ICT Situation in Accra Polytechnic, Ghana Accra Polytechnic started as a technical School in 1949 to train lower and middle level hands-on skilled manpower for industry. Later in 1957, it was upgraded to a Technical Institute and in 1963, renamed Accra Polytechnic by the orders of the first president of Ghana, Osagyefo Dr. Kwame Nkrumah. By the Polytechnic Law, 1992 (PNDC L321), which became fully operative in the 1993/1994 academic year, Accra Polytechnic was elevated and attained a tertiary status. The institution was then placed under the Higher Education Council with an autonomous status. Notwithstanding the difficulties that characterized the quick change over from a secondary to a tertiary institution, Accra Polytechnic has made tremendous progress in its review and expansion of curriculum to suit contemporary needs [3].

New programmes and departments were created as part of the development process. Staff have been trained and re-trained to enhance their capabilities. The polytechnic law was reviewed in 2007 and mandated the institution to award degrees as well as to produce middle level manpower with the requisite hands-on experience for the needs of commerce and industry in Ghana. Thus, the Bachelor of Technology (B-Tech) degree programmes have been introduced as a new option and to give polytechnic HND graduates the opportunity to upgrade themselves. Growth over the years has enabled the polytechnic to develop and improve in infrastructure, teaching and learning facilities [20].

Presently, Accra Polytechnic offers rich curriculum in a variety of programmes and awards Higher National Diploma (HND) certificates through National Board for Professional and Technician Examination (NABPTEX), Ghana and BTech degrees. Thus, in dictates of the objectives and mission of the polytechnic, a wide range of opportunities are being provided for the Ghanaian populace and feeding of industry with the requisite skilled labour. Accra Polytechnic's vision is to become a universally acknowledged centre of excellence for Teaching and Research of applied science, arts and technology and to become a distinguished partner in the provision of Technical, Vocational and Professional Skills to the manpower for the development of Ghana. Accra Polytechnic also has a mission to produce skilled career focused tertiary and middle- level manpower in the areas of manufacturing, commence, science, technology, applied social science and applied arts [20].

\section{Table 3. Data Centre/Server Room}

\begin{tabular}{|c|c|c|}
\hline S/No. & Action & Rationale \\
\hline 1. & $\begin{array}{l}\text { Server Optimization/Virtualization should } \\
\text { be encouraged by the ICT Department of } \\
\text { Accra Polytechnic, which should involve: } \\
\text { - Implementation of storage virtualization } \\
\text { and capacity management. } \\
\text { - Conversion of existing physical servers to } \\
\text { "virtual servers" - partition servers that } \\
\text { run in parallel on the same hardware } \\
\text { without any interference. }\end{array}$ & $\begin{array}{l}\text { - Server optimization/virtualization assists in identifying unused } \\
\text { servers and disks. } \\
\text { - Air-conditioning/cooling equipment typically requires at least } \\
\text { the same power as the servers they cool, consequently reducing } \\
\text { servers may save twice the power required to run them. } \\
\text { - Industry practice has been to run a server using only } 20 \% \text { of its } \\
\text { capacity. Consequently, a server which is switched on but idle } \\
\text { still requires } 50-70 \% \text { of the power it uses when it is running } \\
\text { under maximum load, therefore a single server running at } 80 \% \\
\text { load uses considerably less energy to the benefit of Accra } \\
\text { Polytechnic. }\end{array}$ \\
\hline 2. & $\begin{array}{l}\text { The ICT Department in collaboration with } \\
\text { the Electrical/Electronics Department of } \\
\text { Accra Polytechnic should specify low- } \\
\text { power consumption, low voltage servers } \\
\text { with high-efficiency Power Supply Units } \\
\text { (80\% conversion or better). }\end{array}$ & $\begin{array}{l}\text { - The ICT Department in Accra Polytechnic should not over } \\
\text { specify system requirements. The higher the specification the } \\
\text { more main power is drawn. } \\
\text { - Power Supply Units convert mains AC power to the DC power } \\
\text { needed by computers. More efficient units minimize the loss of } \\
\text { energy from this conversion in the form of heat. }\end{array}$ \\
\hline 3. & $\begin{array}{l}\text { The ICT Department of Accra Polytechnic } \\
\text { should ensure re-use of ICT equipment that } \\
\text { are no longer required but are still } \\
\text { serviceable }\end{array}$ & $\begin{array}{l}\text { - Energy is required to manufacture, distribute and recycle } \\
\text { equipment as well as to use them. } \\
\text { - Extending their use or seeking their re-use elsewhere will save } \\
\text { energy as well as purchase and disposal costs for Accra } \\
\text { Polytechnic. }\end{array}$ \\
\hline 4. & $\begin{array}{l}\text { The ICT Department of Accra Polytechnic } \\
\text { should have a central monitoring system } \\
\text { that will control internet usage by different } \\
\text { users/stakeholders. }\end{array}$ & $\begin{array}{l}\text { - The current bandwidth is limited and consequently, if there is no } \\
\text { control measure, its efficiency is totally reduced. Without any } \\
\text { proper control measure, downloading of non-academic materials } \\
\text { such as video and audio files become prioritized in comparison } \\
\text { to academic material which shouldn't be the case for a tertiary } \\
\text { institution. Such irrelevant downloading introduces e-waste } \\
\text { which increases energy consumption }\end{array}$ \\
\hline 5. & $\begin{array}{l}\text { Accra Polytechnic should adopt a central } \\
\text { inverter to supply power to all ICT } \\
\text { equipment. }\end{array}$ & $\begin{array}{l}\text { - Currently, most ICT equipment are directly connected to the } \\
\text { grid which is unstable. The resulting power fluctuation } \\
\text { contributes to the damage of ICT tools especially computer } \\
\text { motherboards. Moreover, the use of distributed inverters is } \\
\text { accompanied with lack of maintenance. }\end{array}$ \\
\hline
\end{tabular}


Accra Polytechnic has two (2) Departments relating to ICT divided into academic and non-academic. The academic department, Computer Science started which started as a Computer Unit in 1995 and metamorphosed into a Department in 2010 is responsible for all academic and research issues of the Polytechnic and trains students in the HND Computer Science programme. The computer science department manned by a Head of Department consists of lecturers and researchers in the areas of Computer Science and ICT as well as administrative staff and students. The ICT Department established in 2011, which is manned by the Head of ICT, is responsible for the general operation of all ICT issues in the Polytechnic which include:

- Management and maintenance of Accra Polytechnic's Computer Laboratories.

- Provision of Internet and Email services to enhance communications, teaching, learning and research in the Polytechnic.

- Provision of network backbone connectivity - in order to access networked information resources within the Intranet of the Polytechnic (such as the MIS and Library resources) and the Internet.

- Systems Support, Maintenance and Repairs of computer hardware in all departments of the Polytechnic and installation of legal softwares.

- Provision of technical support of Polytechnic's Website and guidance in case of outsourcing.

- ICT Policy and Strategy development and implementation.

- ICT Projects Management in the Polytechnic.

- Provision of ICT Advisory Services to Polytechnic Management.

\subsection{Green ICT Implementation Strategies for Accra Polytechnic, Ghana}

According to [1]-[6], [15], [24], Green ICT can be implemented when the adoption has been accepted and completed. Office equipment is the fastest growing energy user in the business world. The Carbon Trust estimates that it consumes $15 \%$ of the total electricity used in offices, is expected to rise to $30 \%$ by 2020 , with around two-thirds of the energy consumed by office equipment being attributed to computers.

However, the green ICT agenda is not just about energy efficient ICT. ICT can also be used to generate environmental benefits elsewhere in an organization's operations and the wider commercial world. ICT is a key enabler for most Transformational Government programmes, providing better and more efficient services and bringing those services to the public rather than making the public going for them. Green ICT should also play a major role in reducing carbon emissions from other areas of activity, for example through enabling teleconferencing and videoconferencing.

Some relevant objectives of Green ICT include [21]: (i) reducing the amount of energy consumed by ICT equipment/facilities, (ii) ensuring ICT equipment is turned off when not in use, (iii) reducing paper consumption, and (iv) promoting ICT practices that ensure a user friendly environment. Key factors that can strategically be used to achieve these objectives are categorized as follows: (i) Staff Communications, (ii) Data Centres/Server Rooms, (iii) PCs Desktops and Laptops and, (iv) Other Office ICT Equipment. Tables 2-5 provide more details about Actions and Rationales supporting the above categories.

As shown in Table 3 and Fig. 2, server virtualization is the act of creating a virtual version of a server while not limited to the virtual hardware platform, storage devices, operating systems or network resources. Server virtualization can also be defined as the partitioning of a physical server into smaller virtual servers to help maximize server resources. Server virtualization allows more than one server to operate on the same piece of hardware. The server virtualization is a method that has been implemented by different technological firms [22], [24]. The server administrator uses a software application to divide one physical server into multiple isolated virtual environments. The virtual environments are sometimes

Table 4. PCs - Desktops and Laptops

\begin{tabular}{|c|l|l|}
\hline S/No. & Action & Rationale \\
\hline 1. & $\begin{array}{l}\text { All PCs in Accra Polytechnic should be } \\
\text { shut down after office hours. }\end{array}$ & $\begin{array}{l}\text { In Accra Polytechnic, for the default working day of 12 hours the } \\
\text { overnight period lasts for 12 hours. When weekends and holidays } \\
\text { are taken into account Accra Polytechnic could be wasting almost } \\
\text { twice as much energy as consumed during the working day if PCs } \\
\text { are not shut down. }\end{array}$ \\
\hline 2. & $\begin{array}{l}\text { Active screensavers should be removed } \\
\text { from all PCs in Accra Polytechnic. }\end{array}$ & $\begin{array}{l}\text { A monitor left running with an active screen saver uses the same } \\
\text { amount of energy as when the screen is in full use. The PC also } \\
\text { consumes needless power in sustaining the screensaver. }\end{array}$ \\
\hline 3. & $\begin{array}{l}\text { All LCD monitors in Accra Polytechnic } \\
\text { should switch to standby after 5 minutes of } \\
\text { inactivity (no active screensaver). }\end{array}$ & $\begin{array}{l}\text { If nothing on the screen has changed for a long time it is likely } \\
\text { that is no longer being used. Standby mode prevents a longer } \\
\text { period of wasted power. The display can quickly be resumed if it } \\
\text { is indeed in use. }\end{array}$ \\
\hline 4. & $\begin{array}{l}\text { Accra Polytechnic should introduce active } \\
\text { power management on desktops (standby / } \\
\text { hibernate after a defined period of } \\
\text { inactivity). }\end{array}$ & $\begin{array}{l}\text { Having active power management enabled, will more closely } \\
\text { oftch the consumption of energy with use, reducing wasted } \\
\text { energy. PCs can be put into a low energy mode when the user is } \\
\text { away from the desk, e.g. during lunch or at a meeting. }\end{array}$ \\
\hline 5. & $\begin{array}{l}\text { Accra Polytechnic should introduce PC } \\
\text { consolidation. }\end{array}$ & $\begin{array}{l}\text { Reducing the number of electronic devices an individual has will } \\
\text { reduce indirect energy requirements e.g. less support and } \\
\text { maintenance. }\end{array}$ \\
\hline
\end{tabular}


Table 5. Other Office ICT Equipment

\begin{tabular}{|c|l|l|}
\hline S/No. & Action & Rationale \\
\hline 1. & $\begin{array}{l}\text { Accra Polytechnic should apply timer } \\
\text { switches to non-networked technology and } \\
\text { printers }\end{array}$ & $\begin{array}{l}\text { Not all ICT equipment can be networked and/or automatically shut } \\
\text { down or put into standby mode - typically printers, photocopiers } \\
\text { and scanners. Neither do all such devices have automatic facilities } \\
\text { to switch to a standby mode after a pre-set time. } \\
\text { Timer switches can be used to turn off such equipment } \\
\text { automatically outside office hours saving up to 67\% of its daily } \\
\text { energy consumption if currently left on 24 hours a day. }\end{array}$ \\
\hline 2. & $\begin{array}{l}\text { Accra Polytechnic should introduce printer } \\
\text { consolidation }\end{array}$ & $\begin{array}{l}\text { Reducing the number of printers and replacing those left with } \\
\text { networked multi-function devices (MFD) e.g. combined } \\
\text { printers/copiers, can significantly reduce energy consumption. } \\
\text { Fewer printers will also lower maintenance and management } \\
\text { costs. }\end{array}$ \\
\hline
\end{tabular}

called virtual private servers, but they are also known as guests, instances, containers or emulations. Migrating physical servers over to virtual machines and consolidating them onto far fewer physical servers means lowering monthly power and cooling costs in the data centre. This was an early victory chant for server virtualization vendors back in the early part of 2000 , and it still holds true today. Some other significant benefits of server virtualization include: (i) reduction of data centre footprint, (ii) faster server provisioning, (iii) reduction of hardware lock-in, (iv) increase uptime, (v) improvement of disaster recovery, (vi) isolating applications, (vii) extending the life of older applications, and (viii) helping the movement of data through the cloud [23], [24].

\section{RESEARCH DISCUSSION}

Successful green ICT in Accra Polytechnic can be delivered by implementing as many actions from Tables 2-5 as practicable. Specifically:

- The ICT Department in Accra Polytechnic has to enforce and extend the lifecycle of all ICT purchases to their natural demise either caused by failure, inability to support the business objectives of the organization, excessive maintenance costs or excessive carbon footprint and energy consumption, as opposed to frequent automatic refresh and replacement programmes. This should occur where such extensions will have environmental benefits across the product lifecycle and re-deployment of the equipment is not envisaged.

- It is also important for Accra Polytechnic to reduce the overall number of PCs used by the organization to reach as close to a 1:1 ratio as possible unless there are exceptional circumstances.

- The energy efficiency of PCs in Accra Polytechnic should be improved.

- The ICT Department in Accra Polytechnic should implement a range of active device power management actions as detailed in Table 4 to significantly reduce power consumption.

- As discussed in Table 5, there should be a reduction of the overall number of printers used by the organization. The reduction of a large number of printers should be replaced with multi-function devices where practicable and use green printing defaults wherever possible (such as double-sided and multiple pages printing).

As discussed in Tables 2-5, the suitable approach of ensuring successful implementation of green ICT in Accra Polytechnic include:
- Increasing staff awareness of the impact ICT can have and encourage them to think of different ways of working.

- Understanding the resources required, costs of implementation and the issues which need to be addressed if more radical proposals are to be introduced.

- Tasking managers to ensure the environmental consequences of procurements are fully evaluated.

- Providing managers with information about the energy and paper consumption of their service so they can compare the performance of their service with others and assess the impact of any changes they instigate.

\section{CONCLUSION}

This paper described and presented a guide on how to ensure successful strategies of implementing green ICT in Polytechnic Education, specifically, Accra Polytechnic, Ghana. Using relevant literature, the necessity and importance of implementing green ICT in educational institutions as well as its planning, objectives and strategic implementation with a focus on Accra Polytechnic were outlined. Through the adoption of strategic factors such as staff communications, data centre/server room, PCs-desktops and laptops and other office ICT equipment described in this paper, Accra Polytechnic can successfully embark on strategic procedures of implementing green ICT to ensure that its benefits are fully realized.

Although, we observed that some green ICT practices are being done on a very low scale in Accra Polytechnic, a stronger policy is required to improve its current state. This paper therefore recommends more education on green ICT in Accra Polytechnic. Furthermore, Accra Polytechnic should strategically include green ICT in their ICT policy for successful implementation using Sections 5 and 6 of this paper as well as other relevant sources as a guide.

\section{REFERENCES}

[1] Kounatze, C. R. and Vickery, G. 2009. Towards Green ICT Strategies: Assessing Policies and Programmes on ICT and the Environment. OECD Report.

[2] Murugesan, S. 2008. Harnessing Green IT: Principles and Practices. IT Professional IEEE computer Society, $10(1), 24-33$.

[3] Dedrick, J. 2010. Green IS: Concepts and Issues for Information Systems Research. Information Systems Management, 25(2), 159-173. 
[4] Wabwoba, F., Wanyembi, G.W., Omuterema, S., and Mutua, S. M. 2013. Pervasiveness of Green ICT Awareness Amongst Kenyan ICT Personnel. International Journal of Application or Innovation in Engineering and Management, 2(1), 93-104.

[5] Molla A. and Cooper V. A., and Pittayachawan S. 2009. IT and eco-sustainability: Developing and validating a green IT readiness model. In Proceedings of the $13^{\text {th }}$ International Conference on Information Systems (ICIS), 141.

[6] Philipson, G. 2010. A Green ICT Framework: Understanding and Measuring Green ICT. In Connection Research Services Pty Ltd (ABN 47092657 513), Australia.

[7] Hart, S. L. 1997. Beyond Greening: Strategies for a Sustainable World. Harvard Bus. Rev., 75(1), 66-76.

[8] Murugesan, S. and Laplante P. A. 2011. IT for a Greener Planet. IT Professional IEEE Computer Society, 13 (1), $16-18$.

[9] Boughton, C. 2009. What is an ICT Professional Anyway? Australasian Journal of Information Systems, 16 (1), 149-163.

[10] Molla, A. and Cooper, V. A. 2010. Green IT Readiness: A Framework and Preliminary Proof of Concept. Australasian Journal of Information Systems, 16 (2), 523.

[11] Mariani, M. and Imam, K. 2012. A Preliminary Study of Green IT Readiness in Indonesian Organizations. Journal of Energy Technologies and Policy, 2 (5), 1-10.

[12] Hamid S. A. R., Ghafoor, H. A. and Shah T. Z. 2012. Analysis of Attitude Towards Green Purchase: Pakistan in Context. International Journal of Business and Social Science, 3(6), 112-115.

[13] Davis, F. D. 1989. Perceived Usefulness, Perceived Ease of Use, and User Acceptance of Information Technology. MIS Quart., 13(3), 319-339.

[14] Venkatesh, V. and Davis, F. D. 2000. A Theoretical Extension of the Technology Acceptance Model: Four
Longitudinal Field Studies. Management Science, 46 (2), 186-204.

[15] Ogunyemi, A. A. and Johnston, K. A. 2012. Exploring the Roles of People, Governance and Technology in Organizational Readiness for Emerging Technologies. The African Journal of Information Systems, 4 (3), 100119.

[16] Apulu, I. and Latham, A. 2009. Information and Communication Technology Adoption: Challenges for Nigerian SMEs. TMC Academic Journal, 4(2), 64-80.

[17] Alena, B. and Libor, G. 2012. Green ICT Adoption Survey Focused on ICT Life-cycle from the Consumer's Perspective (SMEs). Journal of Competitiveness, 4(4), 109-122.

[18] Page, G. A. and Hill, M. 2008. Information, Communication, and Educational Technologies in Rural Alaska. New Directions for Adult and Continuing Education, 2008 (117), 59-70.

[19] Climate Change in Ghana, Retrieved Online From: https://itunews.itu.int/en/2847-Ghanas-vulnerability-to-climatechange.note.aspx_on 12/01/16.

[20] Accra Polytechnic, Retrieved Online From: www.apoly.edu.gh on 08/01/2016.

[21] Goodall, B. 2008. Green ICT Strategy Efficient, Sustainable, Responsible. The Royal Borough of Kensington and Chelsea, UK.

[22] Mansard, G. 2010. Information and Communication Technology for Industrial Symbiosis. Journal of Industrial Ecology, 14(5), 740-753.

[23] Benefits of Server Virtualization, Retrieved Online From http://www.infoworld.com/article/2621446/servervirtualization/server-virtualization-top-10-benefits-of-servervirtualization.html on 15/01/2016.

[24] Daggag, A. Green Information and Communication Technologies in Small Medium-Sized Companies, Retrieved Online From http://www.asee.org/documents/zones/zone1/2014/Student/PDF s/108.pdf on 17/02/2016. 